\title{
Quality of Life and Health Status of Jordanian Women Users of Various Contraceptive Methods and Associated Factors: Implications for Contraceptive Policies [Corrigendum]
}

\author{
Gharaibeh MK, Alsharm S, Al Maaitah R, Heilat HB, Marayan L. Patient Prefer Adherence. 2022;16:403-412
}

The authors have advised there is an error in the author list and affiliations on page 403. The author name "Lina Marayan" should read "Lina Mrayan", the $1^{\text {st }}$ affiliation should read "Faculty of Nursing, Jordan University of Science and Technology, Irbid, Jordan", the $2^{\text {nd }}$ affilation should read "Faculty of Nursing, Al Ahliyya Amman University, Amman, Jordan", and the $5^{\text {th }}$ affiliation should read "Department of Maternal, Child and Family Health, Faculty of Nursing, The Hashemite University, Zarqa, Jordan".

\section{Publish your work in this journal}

Patient Preference and Adherence is an international, peer-reviewed, open access journal that focusing on the growing importance of patient preference and adherence throughout the therapeutic continuum. Patient satisfaction, acceptability, quality of life, compliance, persistence and their role in developing new therapeutic modalities and compounds to optimize clinical outcomes for existing disease states are major areas of interest for the journal. This journal has been accepted for indexing on PubMed Central. The manuscript management system is completely online and includes a very quick and fair peer-review system, which is all easy to use. Visit http://www.dovepress.com/testimonials.php to read real quotes from published authors. 